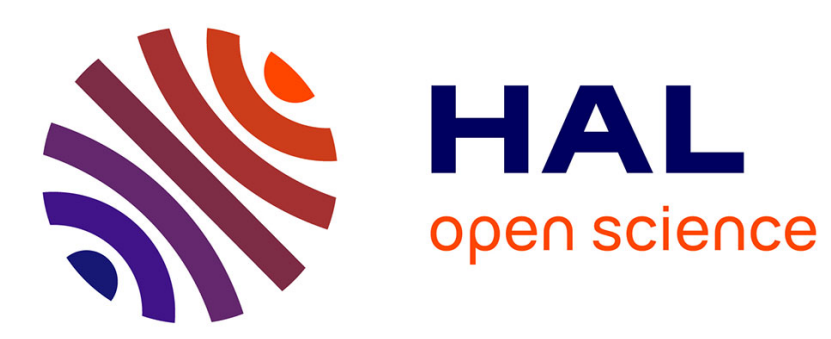

\title{
Magnetic and Magneto-Optical Properties of Nano-Size Bi-YIG Particles Dispersed in a Plastic Binder
}

\author{
Y. Yamazaki, T. Namimawa, T. Hirano, K. Yoshida
}

\section{To cite this version:}

Y. Yamazaki, T. Namimawa, T. Hirano, K. Yoshida. Magnetic and Magneto-Optical Properties of Nano-Size Bi-YIG Particles Dispersed in a Plastic Binder. Journal de Physique IV Proceedings, 1997, 07 (C1), pp.C1-543-C1-544. 10.1051/jp4:19971223 . jpa-00254896

\section{HAL Id: jpa-00254896 https://hal.science/jpa-00254896}

Submitted on 1 Jan 1997

HAL is a multi-disciplinary open access archive for the deposit and dissemination of scientific research documents, whether they are published or not. The documents may come from teaching and research institutions in France or abroad, or from public or private research centers.
L'archive ouverte pluridisciplinaire HAL, est destinée au dépôt et à la diffusion de documents scientifiques de niveau recherche, publiés ou non, émanant des établissements d'enseignement et de recherche français ou étrangers, des laboratoires publics ou privés. 


\title{
Magnetic and Magneto-Optical Properties of Nano-Size Bi-YIG Particles Dispersed in a Plastic Binder
}

\author{
Y. Yamazaki, T. Namimawa, T. Hirano* and K. Yoshida* \\ Tokyo Inst. Tech., Nagatsuta, Midori-ku, Yokohama, 226 Japan \\ * Toppan Printing, TRI, Takanodai-minami, Sugito, Saitama, 345 Japan
}

\begin{abstract}
Magneto-optical films were prepared by coating nano-size Bi-YIG particles, the Faraday rotation of the films were measured. The particle size was changed by milling with a planetary milling machine from $1 \mathrm{~h}$ to $100 \mathrm{~h}$. The magnetic and magneto-optical properties were measured. The $M_{\mathrm{S}}$ of the films dropped with milling time, however, the peak values of Faraday rotation increased. The Faraday rotation spectra of the films changed with particle size. These results indicate that the magneto-optical properties of the coated films differ from those of sputterd films. The figure of merit of the coated films was 3.0 and comparable to that of sputtered films.
\end{abstract}

\section{INTRODUCTION}

Thin films of bismuth substituted yttrium iron garnet (Bi-YIG) are expected to be applied to magneto-optical devices. We have reported that the Faraday rotation spectra of particle-coated films differ from sputtered films [1]. The origin of the spectrum change was presumed to be the change in the interactions between Bi-YIG particles and binder. In this paper, we study the magnetic and magneto-optical properties of the coated films which were made with various size particles.

\section{EXPERIMENTAL}

The $\mathrm{Bi}_{1.8} \mathrm{Y}_{1.2} \mathrm{Fe}_{5} \mathrm{O}_{12}$ particles were prepared by coprecipitation and annealing processes [2]. The crystal phases in the particles were examined by $\mathrm{X}$-ray diffraction analysis. The particles were mixed with an epoxy binder and cyclohexanone. Then the mixtures were milled with a planetary milling machine from 1 to $100 \mathrm{~h}$. The particles were coated by a spin coater. The particles in the films were observed by an atomic-force microscope (AFM). The magnetic properties were measured with a VSM. Absorption coefficient $\alpha$ were measured by a spectrophotometer. Faraday rotation $\theta_{\mathrm{F}}$ were measured by the polarization modulation method.

\section{RESULTS}

Figure 1 shows an AFM image of the caated particles which were milled for $30 \mathrm{~h}$. The size of the particles is about $15 \mathrm{~nm}$. It is noted that the size of the particles is uniform. The mean size of the particles is smaller than the wavelength of visible light. The size of the particles did not change when the milling time extended to $100 \mathrm{~h}$. This result suggests that the size of the primary particles is about $15 \mathrm{~nm}$.

Figure 2 shows the saturation magnetization $M_{\mathrm{s}}$ and in-plane coercive force $H_{\mathrm{C}}$ of the films as a function of the milling time. The $M_{\mathrm{S}}$ and $H_{\mathrm{C}}$ are divided by milling time. The $M_{\mathrm{S}}$ and $H_{\mathrm{C}}$ are dropped during the $1 \sim$ $30 \mathrm{~h}$ milling. This result shows that the non-magnetic surface parts of the particles are increased by pulverization [3]. After $30 \mathrm{~h}$ milling, the magnetic properties of the films did not change with the milling time.

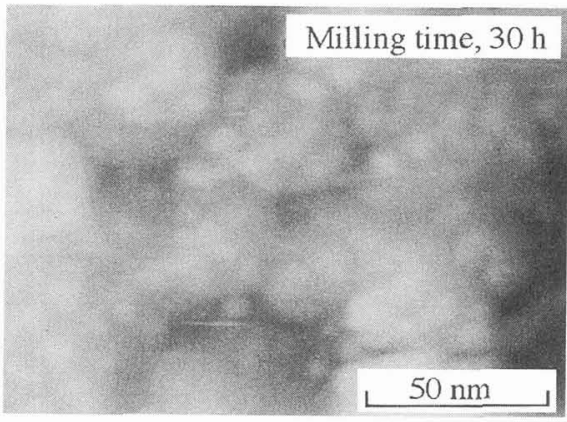

Fig. 1 An AFM image of the Bi-YIG particles coated with a binder. 
Figure 3 shows the Faraday rotation spectra of the coating films. The films containing particles milled over $20 \mathrm{~h}$ show the Faraday rotation spectra which are similar to those of Bi-YIG sputtered films. However, the 1 to $20 \mathrm{~h}$ milled films do not show similar spectrum. The lights were scattered by the Bi-YIG particles in the films which were milled 1 to $20 \mathrm{~h}$, because the size of the particles is nearly equal to the wavelength of the measuring light.

Figure 4 shows $\theta_{F}$ and $\alpha$ of the films as a function of the milling time. The $\alpha$ decreased with milling time. The peak values of Faraday rotation increased with milling time, although the $M_{\mathrm{S}}$ of the films dropped.

The figure of merit of the coating films as a function of the milling time is shown in Fig. 5. The maximum figure of merit was obtained with the coating film containing $30 \mathrm{~h}$-milled particles. The figure of merit of the coated films was 3.0 and comparable to that of sputtered films [4].

\section{CONCLUSIONS}

Nano-size Bi-YIG fine particles were synthesized. Thin films were prepared by coating the fine particles milled from 1 to $100 \mathrm{~h}$. Magnetic and magneto-optical properties of the films were measured.

The peak values of Faraday rotation increased with milling time, however, the $M_{\mathrm{s}}$ of the films dropped. The Faraday rotation spectrum of the films was changed with particle size. These results indicate that the magneto-optical properties of $\mathrm{Bi}$-YIG nano-size particle coating films differ from those of sputterd films.

The figure of merit of the coated films was 3.0 and comparable to that of sputtered films. The Bi-YIG coating film is a new material for magneto-optical devices.

\section{References}

[1] T. Hirano, T. Namikawa and Y. Yamazaki, DENKI KAGAKU, 64(4), 307 (1996).

[2] T. Hirano, T. Namikawa and Y. Yamazaki, IEEE Trans. Magn., 31(6), 3280 (1995).

[3] A. H. Morrish and K. Haneda, J. Magn. Magn. Mater., 35, 105 (1983).

[4] M. Gomi, T. Taneda and M. Abe, J. Appl. Phys., 57(1), 3888 (1985).

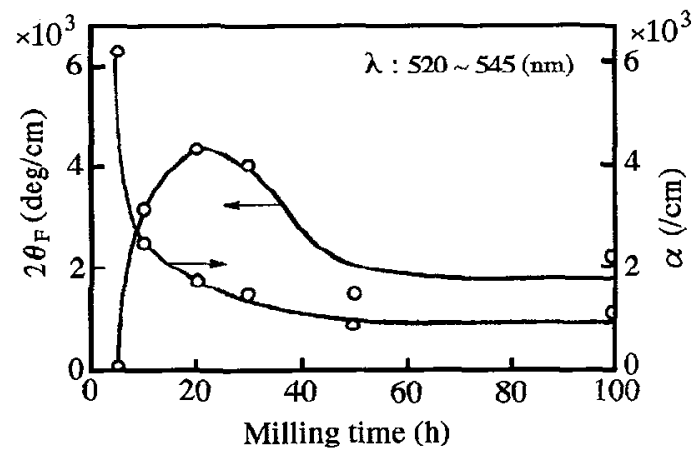

Fig.4 Faraday rotation $\theta_{\mathrm{F}}$ and absorption coefficient $\alpha$ as a function of the milling time.

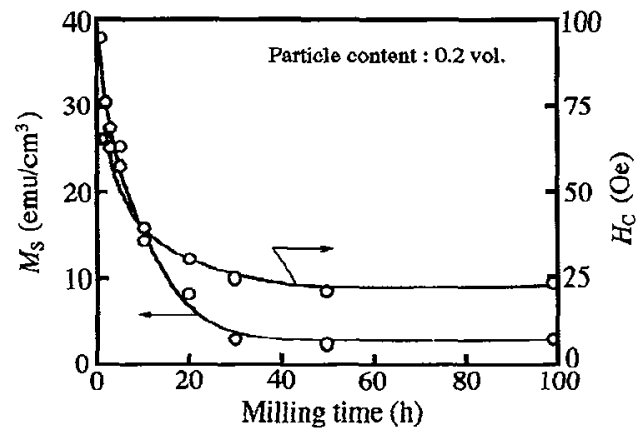

Fig.2 Saturation magnetization and coercive force as a function of the milling time.

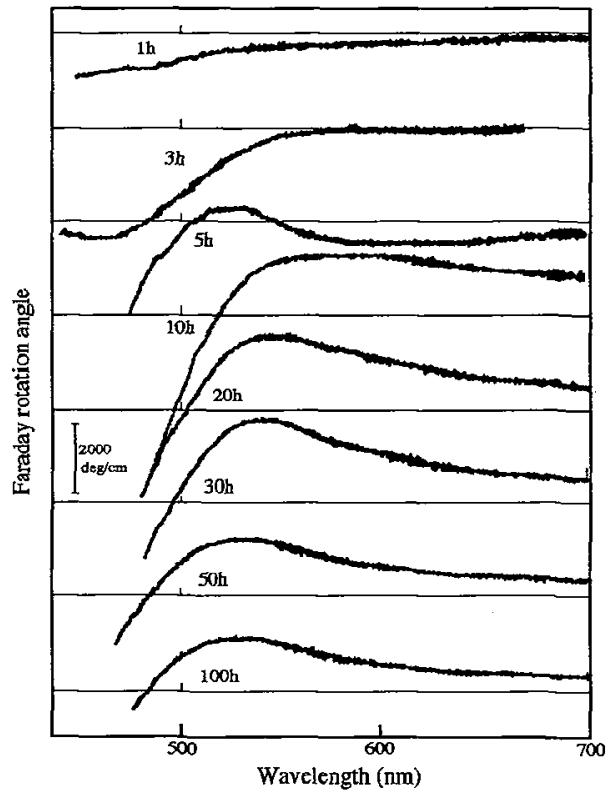

Fig.3 Faraday rotation spectra of Bi-YIG coating films.

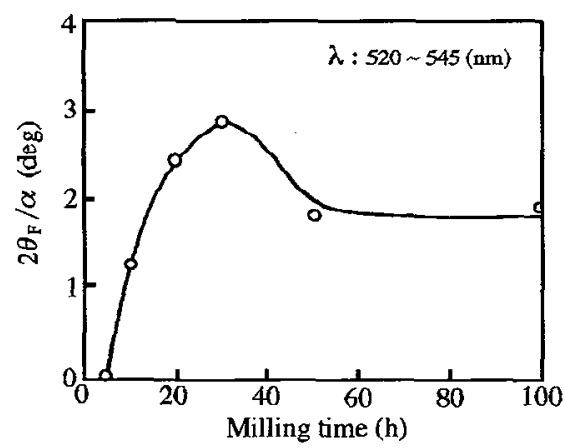

Fig.5 Figure of merit as a function of the milling time. 